\title{
6
}

\section{Narrative Practice and Free Indirect Style}

Style. 1. An instrument used by the ancients in writing on waxed tables. 2. Anything resembling the ancient style in shape or use; as: $a$ A pen. $b$ A graver. $c$ An etching needle. $d$. A phonograph needle. $e$ The pin, or gnomon, of a dial. $f$ Surg. A stylet; probe. 3. Mode of expressing thought in language; esp., such use of language as exhibits the spirit and personality of an artist; characteristic mode of expression; as, a terse style.

Stylite. One of a class of ascetics who lived on tops of pillars. Webster's New Collegiate Dictionary

In this chapter we shall turn from general features of Flaubert's "dual style" to specific problems in his mode of narration. Flaubert's narrative practice in Madame Bovary combines extended passages of "objective" or "impassive" description, very brief interludes of quoted dialogue or interior monologue, and significant use of so-called "free indirect style." The rhythm of his narration, as well as the interplay between unifying and disseminating forces in it, is a function of the way these narrative procedures are woven together. When shifts in narrative procedure are drastic enough, the text threatens to become unstitched as more uncanny or unsettlingly carnivalesque forces come into play. Perhaps the most puzzling dimension of Flaubert's narrative practice is the so-called "free indirect style" whose significance we have already encountered.

Free indirect style has the peculiarity of being very easy to recognize but rather difficult to analyze. Commentators will 


\section{Narrative Practice and Free Indirect Style}

invariably agree on the selection of passages in which it is present, but they will vary significantly in their explanations of it. The free indirect style should not be isolated from Flaubert's narrative practice in general; it should be seen in the larger context of shifting narrative perspectives that typifies his approach to narration. For free indirect style applies within a passage the modulation of perspectives or "voice" that the combination of objective narration, quoted dialogue, interior monologue, and free indirect style itself effects among passages in the comprehensive narrative movement. And the issue of narrative perspective itself relates to the even more general problem of the nature and implications of the interaction between unifying and disseminating forces in the novel as a whole. Indeed the question of "style" and of narrative practice cannot be separated from the larger sociocultural and political issues we have already raised. One of the preoccupations at Flaubert's trial, it may be recalled, was whether there was a unified and reliable center of judgment in the novel, as well as the consequences of its presence or absence.

The trial of course did not investigate the problem of the so-called free indirect style. And Flaubert himself does not use the term style indirect libre. In fact he says relatively little in his letters that bears directly on the concept. By contrast, he expatiates on the in's and out's of impersonal or impassive narration, and at times he discusses the seemingly opposed possibility of losing himself entirely in what he is writing. It should not be surprising that the extremes of total, transcendental objectivity and of mystical immanence meet. Indeed for Flaubert the height of impersonality eliminated the particular forms of subjectivity, as did complete merger of the narrating self with the object of narration. "You are disseminated in all. Your personages live and instead of an eternal declamatory personality, which cannot even be clearly constituted given the lack of precise details through the travesties which disguise it, one will see human crowds in your works" (March 27, 1852).

The problem, however, is whether the distribution of the narrative self is in practice more complex than is indicated in the unmediated extremes of impassive transcendence and mystical pantheism. A number of commentators have underem- 


\section{Madame Bovary on Trial}

phasized the complexities of narration in Flaubert and stressed instead the role of the narrator as impersonal or hidden God, present everywhere and visible nowhere-although they have also noted the presence of more mystical or pantheistic ideas in the letters. Anthony Thorlby's formulation agrees in many respects with that of Sartre. He argues that the ideal of impersonal narration sacrificed "the values of personality to an impersonal ideal of the truth, an ideal which virtually denied the value of existence altogether, while maintaining the validity of a kind of absolute knowledge." This view corresponds to Sartre's analysis of the quest for pure art through the principle of "survol" whereby the narrator-author, in a stable ironic position, is a transcendental ego having a nihilating relation to characters and to deceptively realistic details. The superior joke played by this narrator would be on the puppetlike characters and on demoralized readers, for the narrator would be securely hors jeu. The narrator would keep his hidden hands clean (or, in the more equivocal phrase of James Joyce, be off

1. Gustave Flaubert and the Art of Realism (London: Bowes \& Bowes, 1956), 138. For many recent commentators, the "absolute knowledge" sought by Flaubert merged with his quest for pure art. The resultant knowledge was a mode of absolute negativity, the realism purely linguistic, and the conception of language self-referential. Along this interpretative path commentaries related to non-Sartrean perspectives can converge with the conclusions of Sartre's Idiot or assimilate aspects of it in a seemingly unproblematic way. This tendency at times appears in Jonathan Culler's Flaubert: The Uses of Uncertainty (Ithaca: Cornell University Press, 1974). It also surfaces in Naomi Schor's "Pour Une Thématique Restreinte: Ecriture, parole et différence dans Madame Bovary," Littérature (May, 1976), 30-42. For Schor, the various structural oppositions employed and undermined in Madame Bovary are "as if transcended [dépassées] by Flaubert's radical distrust of language in general" (p. 43). Leo Bersani, in Balzac to Beckett (New York: Oxford University Press, 197o), presents Madame Bovary as the realization of Flaubert's quest for pure art as purely autotelic language: "Flaubert's novels are most interestingly about . . . the arbitrary, insignificant, inexpressive nature of language. . . Fundamentally, language refers to nothing beyond its own impersonal (and discouraging) virtuosity" ( $p$. 144). The problem of language is of course at issue in Madame Bovary in ways these studies often illuminate brilliantly. And their specific discussions of Flaubert's writing frequently place in question an overly facile dichotomy between the "positive" and "negative" dimensions of language use, thereby intimating that the process of self-contestation in Flaubert's novels may be a direct or indirect force for renewal. The tendency to converge with Sartre's conclusions, however, threatens to obviate the need for a more complex investigation of the manner in which this process engages broader sociocultural issues. 
somewhere paring his fingernails). The pantheistic tendencies expressed in Flaubert's letters might from this perspective be put down to the "double binds" that were brought about by pathological passivity or "pithiatism." The narrator would never be present in his own human voice but would oscillate between a securely ironic impersonality and a mystical or pantheistic swooning.

This view is too restricted to enable an understanding of the modulations of perspective or voice in Flaubert's narrative practice, including the workings of the "free indirect style." Given the difficulty in elucidating the latter, my own procedure will be to discuss three of the most important attempts in English to provide a theoretical account of it and then to comment critically upon them. The seminal works of Stephen Ullmann, Dorrit Cohn, and Roy $\mathrm{Pascal}^{2}$ are especially instructive in that they tend to summarize existing scholarship on the relevant issues.

Many of Ullmann's suggestions are taken up and developed by Cohn and Pascal. Ullmann notes that, in free indirect style, the narrator does not simply report in a neutral or impersonal way that something occurred. Nor does he directly express his own subjective views or quote the words of characters. As Ullmann concisely puts it:

1. The very existence of the construction makes for variety in style. The author can choose between three different forms of

2. Stephen Ullmann, Style in the French Novel (New York: Barnes \& Noble, 1964); Dorrit Cohn, Transparent Minds: Narrative Modes for Presenting Consciousness in Fiction (Princeton: Princeton University Press, 1978); Roy Pascal, The Dual Voice: Free Indirect Speech and Its Functioning in the Nineteenth-Century European Novel (Manchester: Manchester University Press, 1977). See also Marguerite Lips, Le Style indirect libre (Paris: Payot, 1926); Albert Thibaudet, Gustave Flaubert [1922] (Paris: Gallimard, 1935), 22 1-85; and especially V. N. Vološinov, Marxism and the Philosophy of Language [193o], trans. Ladislav Matejka and I. R. Titunik (New York: Seminar Press, 1973). Vološinov furnishes a penetrating study of the entire problem of "reported speech." He also of fers an analysis and critique of the contrasting approaches to the study of language of Saussure and Karl Vossler. E. Lorck and E. Lerch were members of the Vosslerian school which was especially important in Germany in contrast to the role of the Saussurian school in the French-language context. For a discussion of the moot issue of the precise nature of the undoubtedly close relation of Vološinov to M. M. Bakhtin, see Tzvetan Todorov, Mikhail Bakhtine: le principe dialogique (Paris: Editions du Seuil, 1981). 
reported speech [direct, indirect, and free indirect] and can alternate them in a number of ways.

2. Free indirect style combines the advantages of the two orthodox methods. The author is not committed to an exact reproduction of words or thoughts; yet he is able to dispense with explicit subordination [involved in phrases such as "he said that" or "he felt that"] and to retain the emotive and expressive features and the very inflexions of the spoken language.

3. Free indirect style is reported speech masquerading as narrative. It means a break in continuity and a certain shock to the reader. It is essentially an oblique construction and provides a discreet but effective vehicle for irony and ambiguity and for the description of reveries, dreams, and hallucinatory states. $^{3}$

Ullmann remarks that the use of free indirect style was quite uncommon in the Enlightenment during which more clear-cut and analytic methods of language use were preferred. (La Fontaine, whom Flaubert greatly admired, was one noteworthy exception.) But Ullmann also notes that free indirect style is to be found in the very first French literary text on record, "The Sequence of Saint Eulalia." Departing from Ullmann's own commentary, one may perhaps add that it is both fitting and ironic that free indirect style is employed in a text with a religious subject and that the tale involves a loss of virginity or a primary form of transgression. Indeed the proper name Eulalia evokes the common noun eulalia, hence speaking in tongues and echo effects. Flaubert was always concerned with the problems of purity and transgression, and, in his relation to canonized uses of language, he put into practice a strategy of citation with effects of irony and empathy that are epitomized in the free indirect style. Flaubert's relation to cliché and to conventionalized social or literary discourse brought into play an elaborate use of echo effects with modulations of complicity and distance in the relation between the narrative self and the narrated object. The writer necessarily spoke in the tongues of given social and literary discourse, but the crucial issue was the

3. Ullmann, Style in the French Novel, 116. 
nature of the variations he played upon them. ${ }^{4}$ With respect to the problem of purity and transgression, one may quote from a letter written just prior to the composition of Madame Bovary where Flaubert enunciates three subjects:

As for subjects, I have three, perhaps they are all the same, a thought that galls me considerably. One: Une Nuit de Don Juan, which I thought of in quarantine at Rhodes. Two: Anubis, the story of the woman who wants to be laid by the god. This is the loftiest of the three, but full of atrocious difficulties. Three: my Flemish novel about the young girl who dies a virgin and mystic after living with her father and mother in a small provincial town, at the end of a garden full of cabbages and fruit trees beside a stream the size of the Robec. What torments me is the kinship of idea of these three projects. In the first, insatiable love in the two forms: earthly love and mystical love. In the second, the same story, only there is fornication in it, and the earthly love is less exalted because more precise. In the third they are combined in the same person, and the one leads to the other; only my heroine dies of religious masturbation after indulging in digital masturbation. Alas! It seems to me that when one is as good as this at dissecting children yet to be born, one doesn't harden up enough to create them. My clear-cut metaphysics fills me with terrors. [November 14, $185^{\circ}$ ]

The third story was indeed "hardened up" and transformed into Madame Bovary. The second bears some resemblance to Salammbô. And Francis Steegmuller notes of the first: "Flaubert's outline for Une Nuit de Don Juan exists. It consists chiefly of two dialogues: between the Don and Leparello, about the Don's way of life; and between the Don and a nun with whom he spends the night in her convent, about earthly and mystical

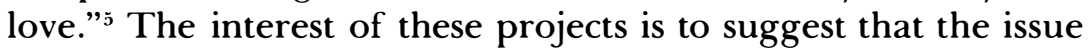

4. On the general problem of quotation in the novel, see Hermann Meyer, The Poetics of Quotation in the European Novel [1961], trans. Theodore and Yette Ziolkowski (Princeton: Princeton University Press, 1968); and Gerhard R. Kaiser, Proust-Musil-Joyce: Zum Verhältnis von Literatur und Gesellschaft am Paradigma des Zitats (Frankfurt a. M.: Athenaum, 1972).

5. The Letters of Gustave Flaubert 1830-1857 (Cambridge: Harvard University Press, 1980), 131. 
of narration engages problems of language use and metaphysical pathos that characterize not only limited sketches but Flaubert's entire lifework.

Flaubert's novelistic world is one wherein the clear and present danger is the systematic profanation of ideals culminating in the addled nature of ideals themselves. This constant state of trivialized transgression threatens to make all actions and words either hypocritical or parodic. It deprives transgression itself of its possible fascination, for there is no real temptation when everything is profaned. What this world lacked is an engaging tension between commitment and transgression-the social and personal rhythm that sets up a viable interplay among the affirmation of norms, the allure of forbidden desire, and the evanescent effulgence of liminal invitations or nonfixated events of "transcendence." Indeed the ideal of pure art was itself a fleeting image of transcendence that Flaubert was tempted to convert into a fetish. Yet it had to be transgressedand nowhere more insistently and subtly than in the modulations of the "free indirect style." For the latter was in some sense a mode of "impurity" in the complex relation of narrator and narrated, yet one that held out some promise of recreating a relational network more worthy of affirmation.

Dorrit Cohn centers her ambitious study around the problem of the representation of consciousness in fiction. There are difficulties with the terms in which Cohn articulates the problem as well as with the general idea that the very uniqueness of fictional uses of language lies in the representation of consciousness. ${ }^{6}$ But we shall touch upon these difficulties only as they bear upon specific points in the analysis of the "free indirect style."

Cohn distinguishes among three modes of narration. "Psychonarration" is a consciousness-centered variant of objective narration in which one has the author's discourse about the mind of a character. "Quoted monologue" is Cohn's term for the more standard notion of stream of consciousness wherein the "mental discourse" of the character is directly rendered. "Narrated monologue" is Cohn's suggested term to encompass

6. Cohn, Transparent Minds, 7 . 
free indirect style. Cohn's account of narrated monologue is close to Ullmann's idea of "reported speech masquerading as narrative." As Cohn puts it: "Linguistically it is the most complex of the three techniques: like psychonarration it maintains the third-person reference and [past] tense of narration, but like the quoted monologue, it reproduces verbatim the character's own mental language." Thus:

It may be most succinctly defined as the technique for rendering a character's thought in his own idiom while maintaining the third-person reference and the basic tense of narration. This definition implies that a simple transposition of grammatical person [from third to first] and tense [from past to present] will "translate" a narrated into an interior monologue. Such translation can actually be applied as a kind of litmus test to confirm the validity of a reader's apprehension that a narrative sentence belongs to a character's, rather than to a narrator's, mental domain. ${ }^{8}$

Cohn will also argue that the relation of the narrator to the character's "mental language," "thought," or "mental domain" will involve variable forms of irony and empathy.

Concerning Flaubert, Cohn writes:

The decisive turning point for the narrated monologue came, of course, with Flaubert. Perceptive students of his style agree that his systematic employment of the style indirect libre is his most influential formal achievement. . . . Flaubert himself, when he comments on his impersonal narrative method, employs phrases that come close to pinpointing the narrated monologue itself, especially in the following passage to Georges Sand [December 15-16, 1866]: "I expressed myself badly when I told you that 'one should not write with one's personality on stage.' I believe that great Art is scientific and impersonal. One should, by an effort of the spirit, transport oneself into the characters, not draw them to oneself. That, at any rate, is the method." [Cohn's emphasis] Translating this kinetic image into linguistic terms would yield an exact de-

7. Ibid., 14 .

8. Ibid., 100-101. 


\section{Madame Bovary on Trial}

scription of the narrated monologue-as would the theological image Flaubert used elsewhere, when he referred to the "faculté panthéiste."

Cohn notes that the possibility of an "insensible shading of narrated monologue into psychonarration is very frequent in figural [character-oriented] narrative situations." But she still tends to see this shading as a borderline phenomenon and asserts that it does not in any case typify Flaubert's novels where "the lines between the techniques are clearly marked." 10 To illustrate this point, Cohn quotes the following passage from Madame Bovary where the italics are inserted by Cohn to designate narrated monologue:

Then she tried to calm down; she remembered the letter. It had to be finished, but she didn't dare. Besides, where? How? She would be seen.

—No, she thought, here I'll be alright."

Cohn notes that free indirect style (or "narrated monologue") generates the problem of the relation between the narrator and the narrated-notably the character's "mental language," "thought," or "mental domain." But the vacillation in the characterizations of what it is in the character that is rendered by the narrator indicates the problem in Cohn's analysis itself. The term "narrated monologue" may of course be introduced to denote the case wherein a narrator narrates in the third person the "thoughts" of a character in that character's own language or idiom. But the term then fails to cover Flaubert's practice in style indirect libre. In Flaubert it may be the case that the language is such that the character himself might employ it (with appropriate changes in person and tense). In other cases, however, this is either not clearly, or clearly not, the case. The very term "monologue" obscures what would seem distinctive about free indirect style: the creation of a dialogical relation of a complex sort between narrator and character. The narrator is both

9. Ibid., $113^{-14}$.

10. Ibid., 136 .

11. Quoted, ibid., 134-35. 
inside and outside the character's "mind" in a manner involving variations of irony and empathy. The use of the character's own words or types of discourse would have ironic effect only in cases where the nature of that discourse can be counted upon to "self-destruct," as in the case of Homais' pomposity or at times of Emma's romantic clichés. But the ironic effect of what Walter Benjamin saw as phosphorescent, self-exploding quotation may backfire, for it may pass unperceived by the reader. The more general point is that the language used in free indirect style has differential relations to the language typical of characters, and these differential relations are bound up with modulations of irony and empathy. Cohn notes the role of the latter but provides a definition or "litmus" of the "narrated monologue" that fails to account for them. A basic consideration would seem to be that the free indirect style is in some sense a threshold or highly ambivalent phenomenon involving various degrees of liminality in the relation of the narrator and the narrated. The intricate dialogical possibilities in this relation are obscured or obliterated when stress is placed on monologue or on the report of a character's thought or speech. (It is of course "dialogization" that Bakhtin relates to highly carnivalized uses of language.) The quote from Flaubert's letter to Georges Sand itself seems to vacillate between objective impersonality and subjective identification in attempting to describe a mode of narration whose very criterion would seem to be the ability to undercut or problematize the opposition between the objective and the subjective (or the ironic-impersonal and the empathetic-pantheistic). It is this very ability that may have uncanny effects related to an indeterminacy of narrative voice and to a possible rendition or "representation" of more unconscious and "primary" processes in language use. Indeed what Cohn would like to confine to a borderline case and to exclude from Flaubert's practice altogether would seem to be typical of the very marginal or liminal possibilities of style indirect libre itself. For this "style" involves a dialogue between narrator and character that assumes changing positions on the threshold between "self" and "other."

Roy Pascal's study is more limited in scope than Dorrit Cohn's, but it is in many ways more directly related to certain 


\section{Madame Bovary on Trial}

of the issues I have tried to raise. The studies of Pascal and Cohn were published within a year of one another, and it is useful to compare them on certain key points. Pascal's work helps to situate certain of Cohn's tendencies while it joins up with them in a number of respects. Most remarkable is a discrepancy between the theoretical observations of Pascal and the directions taken in his particular discussion (or "practical criticism") of Flaubert. Given the interest of a number of his theoretical and historical comments, however, it is worthwhile to quote Pascal at length. Indeed what is striking in his study is his apparent critical self-doubt about the very terminology used to designate the nature and workings of "free indirect style." (Cohn's selection of another term might also be seen as a sign of dissatisfaction with traditional terminology and attendant analyses.)

Pascal observes that the style indirect libre was first named and analyzed in 1912 by the linguist Charles Bally, a former pupil of Ferdinand de Saussure. And Bally himself initiated the attempt to relate grammatical criteria to broader discursive considerations.

Since this ... form has the pronouns and tenses of simple indirect speech, Bally considered its name should indicate this relationship. Further, since in distinction from simple indirect speech, it has no linking conjunctions ("that," "whether," etc.), and may often lack the introductory verb, verbum dicendi or credendi ("he said," "he thought," etc.), Bally associated the term "free" with "indirect." He noted, however, that the form has some of the distinctive features of direct speech, and gives the feeling of direct speech. While simple indirect speech tends to obliterate the characteristic personal idiom of the reported speaker, [style indirect libre] preserves some of its elements - the sentence form, questions and exclamations, intonation, and the personal vocabulary-just as it preserves the subjective perspective of the character. . . Bally acknowledged that [style indirect libre] cannot be defined solely in grammatical terms. On grammatical grounds it often cannot be distinguished from normal authorial report, and as a result pointers like "he thought" may be required to make it clear that a statement emanates from the character and not from 


\section{Narrative Practice and Free Indirect Style}

the author. Frequently the reader cannot, in fact, be sure whether the statement belongs to one or the other. ${ }^{12}$

The last consideration in the above quote broaches the problem of a possible indeterminacy of voice in the style indirect libre or the way in which a use of language may play in two registers - those of the character and the narrator-with the possible modulations of irony and empathy this entails. Pascal himself stresses this possibility in his title-Dual Voice-and helps to situate Cohn's emphasis upon identification of narrator with character (or the narration of a character's monologue) as one end of a spectrum or sliding scale of possibilities. At least, Pascal does this in theoretical terms, although even on this level there are hesitations or equivocations in his account. For example, he disagrees with Bally's view that free indirect style is a literary in contrast with a normal or ordinary use of language, and he cites as evidence for its ordinary usage the fact that writers such as Jane Austen, who apparently do not draw from a literary heritage in their employment of it, nonetheless make such fluent and effortless use of the form. Yet he does agree with Bally's extremely rationalistic derivation of free indirect style from indirect speech by "the simple elimination of the wearisome repetition of verbal introductions like 'he said,' 'he thought,' and of repeated conjunctions-'he said that . . . that ..., and that ...' etc."' ${ }^{\prime 3}$ This inference would make free indirect style derivative on purely speculative grounds which are, I think, related to the metaphysical desire (also evident in Cohn) to subordinate sharply more liminal or ambivalent forms to clear and distinct, analytically separable ones.

Pascal argues that Bally's analysis and terminology have lasting value, and he contrasts them with what he sees as the more dubious Germanic legacy of reflection on the issue. Etienne Lorck coined the term "Erlebte Rede" in his book (1921) of that title, and he was critical of Bally for not seeking the "spirit" behind grammar. Like another German scholar of the time-Eugen Lerch-Lorck made the direct evocation of char-

12. Pascal, Dual Voice, 9-10.

13. Ibid., 10. 
acter the distinctive feature of "experienced speech." For Lorck, the style "arose in a state of intense imagination, when the writer so identifies himself with the creatures of his imagination that he 'inwardly experiences' what they experience." ${ }^{4}$ (Thus one may further situate Dorrit Cohn's approach in the Germanic tradition, although in Cohn the focus shifts from writer or author to narrator, and the greatest possible diminution of distance between narrator and character is seen in terms of identification rather than of full identity, thereby allowing in some way for irony. One may also note that Sartre's readiness to read texts symptomatically or confessionally as authorial expressions owes much to the tradition of Lebensphilosophie as practiced, for example, in the work of Wilhelm Dilthey and, at times, in the early Heidegger.)

The chief reason Lorck invented the term "erlebte Rede" was to stress the irrational and rapturous in contrast to the informational function of language. It was thus related to philosophies of "life" and immediate "experience." Pascal demurs from a discussion of Lorck's philosophy of language and takes issue with him on "stylistic" grounds.

In his theory, as in his analysis of texts, Lorck fails to recognize the narratorial function of the "style indirect libre." Almost all critics and linguists, among them Stephen Ullmann and Norman Page, have recognized that it fuses the narratorial and the subjective modes. Lorck uses a similar phrase, but in fact ignores everything apart from the subjective function, the direct evocation of the character, the contrast to simple indirect speech and to normal narratorial description. But [style indirect libre] always embodies a narratorial element, clearly proclaimed in the first place through the verbal tense and the pronomial forms. The narratorial presence is communicated in three main ways: through the vocabulary and idiom, through the composition of the sentences and the larger passages, and through the context. ${ }^{15}$

In Cohn the narrator tended to become a cipher for the character's impressions. Pascal sets up the duality of the rela-

14. Ibid., 22.

15. Ibid., 25. 


\section{Narrative Practice and Free Indirect Style}

tion between character and narrator-a duality that is neither a dualism nor an identity. "Always the language is mixed, implying an interpreting intermediary; often of course it bears a strong implicit narratorial comment, notably of irony." ${ }^{16}$ Pascal's own strictures should be kept in mind when we come to his discussion of Flaubert, for then Pascal himself tends to gravitate back in the direction of restricting the role of the narrator to a largely passive function. Before reaching this point, we may quote Pascal's definition of free indirect speech (the term he prefers) as well as certain remarks he makes concerning the relation between it and history or historiography.

Free indirect speech is a stylistic device based upon the form of simple indirect (reported) speech, i.e. using the tenses and person proper to the latter. It injects into this rather colourless form the vivacity of direct speech, evoking the personal tone, the gesture, and often the idiom of the speaker or thinker reported. In its simplest form it is found in the mimicry of odd expressions characteristic of a person, but in more complex, extensive forms is used for the dialogue and the articulate soliloquy, short or long, as also for pre-verbal levels of nervous and mental responses and non-verbal registrations of sense-impressions, ranging from the most evident and readily expressed observations to the most obscure movements of the psyche. ${ }^{17}$

Pascal cautions against a conventional idea of a history of free indirect speech, and the terms of his argument suggest an understanding of its role over time in terms of a process of repetition with varying degrees of dominance or submergence in relation to other forms:

To conceive of a history of [free indirect speech] invites a misunderstanding. For, although the form crops up here and there since the Middle Ages, there is until modern times, after Flaubert, no continuous tradition of its use and transmission as a literary technique; until Flaubert no writer seems to have

16. Ibid., 26.

17. Ibid., ${ }^{1} 3^{6-} 37$. 


\section{Madame Bovary on Trial}

used it with a clear consciousness of its stylistic identity and meaning. So that, although one can observe its appearance in this or that author since the Renaissance, one cannot draw a graph of a tradition or of an evolution from crude beginnings to artistic accomplishment. Indeed, when it first appears as a prominent and continuous feature in a novel, in Goethe and Jane Austen, it is already used with the greatest skill and propriety. This fact alone seems to suggest that, with such slight literary antecedents, there must be some linguistic habit in common usage on which these authors were drawing. ${ }^{18}$

These apposite remarks would seem to exclude not the possibility of a history of the form but rather of a certain preconceived idea of history itself as a continuous, developmental, teleologically oriented unfolding of a principle. Yet Pascal will relate the prevalence of free indirect speech to the relative importance in modern fiction of "the depiction of states of mind, temperament, moods, rather than external actions." ${ }^{19}$ This concordance with Cohn's emphasis upon the "artist's journey to the interior" may, however, be too simple an explanation to account for the prevalence of free indirect style which involves varying degrees of proximity and distance between (narrative) self and (narrated) other as well as the problem of variable positions of the narrating subject itself, not to mention its relation to the authorial or biographical self. Indeed I would offer the speculation that the larger cultural context that induces or facilitates the widespread use of free indirect style at least in the form it takes in Flaubert is one wherein the writer is fairly definite about what he rejects in the larger society (for example, "bourgeois stupidity") but relatively uncertain and clearly undogmatic about viable alternatives. In this sense, the free indirect style might be seen (in an extension of Bakhtin's analysis) as a complex, exploratory, and often muted form of satire with carnivalesque features. It involves a dialogue not only between self and objectified other but one within the self-a dialogue entailing a high degree of uncertainty and doubt. It is a procedure that is effective and potentially disorienting in

18. Ibid., 34 .

19. Ibid., 34 . 
sounding out accepted conventions, clichés, and modes of discourse, and the degree of undecidability it puts into play may go to extremes. Indeed its more exorbitant forms reinforce the rapid or drastic oscillations of Flaubert's general narrative practice to create a dismemberment or distribution of the narrative self that is extremely difficult to track. This limit marks the point of intersection between critical and uncannily disquieting forces in more hyperbolic movements of a carnivalized "style." And it raises in a particularly insistent way the question of the interaction among symptomatic, critical, and transformative effects in the relation between writing and culture.

It is interesting that Pascal cautions against the use of free indirect style in historiography and literary criticism, although he sees some use of it as inevitable. It is not (as in Cohn) the representation of consciousness in general but rather free indirect speech that should be primarily confined to fiction. (Cohn's view would place psychology, psychobiography, and an important variant of the history of ideas in peculiarly untenable positions.)

Free indirect speech postulates a relationship between narrator and character, a knowledge of the inner processes of another person that can never exist in real life, and that inevitably introduces a fictional element if it is used in historical writing. ... I think historians feel the same resistance about the use of free indirect speech, and are well advised to prefer the actual words of their historical characters or a narrative form that clearly demarcates the sphere of the narrator from that of the character. ${ }^{20}$

One may conclude from these remarks that the historian should largely restrict himself to direct quotation, and, when he departs from its complement in objective narration, he should make clear the nature of inferences about "inner" states and the positions of self and other in any dialogue with the past. Pascal is warranted in emphasizing the need for special controls in the use of mixed modes involving an ambivalent interplay of

2o. Ibid., 136 . 


\section{Madame Bovary on Trial}

proximity and distance, empathy and irony, in historical or "nonfictional" uses of language. At the very least, the nature of fictions and of their use in framing hypotheses or in orienting research should, one might argue, be subject to checks. Yet the idea that the historian is an author who narrates in his own objective voice or clearly and distinctly quotes and documents the "voices" of others begs a number of questions. To what extent does all writing in more or less distinctive ways involve a difference between author and narrator with the possibility that the narrator will take certain liberties with language or have them taken (perhaps unawares) with him? To what extent are there differential norms regulating the relation of author and narrator in different areas or "genres" of writing and to what extent are they subject to variation or question over time? How do "modern" contextual constraints bear upon the writing of history or criticism? When the historian, for example, does not speak in his own voice or is even uncertain as to the nature of that "voice," does he simply cease writing history? ("C'est beau, peut-être, mais ce n'est pas de l'histoire," a voice says. Whose voice? Certainly not the voice of the historian but a higher-order, "metahistorical" voice that defines what is to count as history.) Should one attempt to recast the relations among genres or areas of discourse in terms of norms regulating author-narrator relations: fiction at one end-that of disquieting play-and history at another-that of reassuring veracity-with other discursive modes such as philosophy falling somewhere in between or perhaps rising masterfully above? Does this neo-Aristotelian enterprise founder-or at least leave open certain questions that both situate and are situated by it? How do, and how should, distinctions of degree relate to oppositions of kind? What does one do with intractably realistic aspects of fiction or fictive dimensions of historical narration? With these questions one of course enters the babellike scene of contemporary controversy about the nature of discourse.

What is significant in the recent past is the subversion of the norms that Pascal seems to take for granted. In Sartre's own Idiot de la famille, something approaching a generalized free indirect method of inquiry of ten makes it difficult to distin- 


\section{Narrative Practice and Free Indirect Style}

guish between fact and fiction in the account which Sartre himself terms a "true novel." The free indirect method is essential to "fictionalized" modes of reporting in general, for example, in the work of Norman Mailer. And, from a different direction, recent literary criticism that seeks to undermine the category of the author, question the status of the "signature," and stress the anonymity of language use in a critical discourse that "creatively" rewrites or emulates its object seems, when taken to the limit, to generalize a free indirect style in a rather discomforting way. One may note that, in his specific commentary on Flaubert, Pascal himself seems to draw back from the more disconcerting uses of free indirect speech in fiction itself.

Of Flaubert, Pascal asserts:

His avowed aim was to get away from the obtrusive narrator of the novel, the author who directs our attention, explains events and people to us, and proffers moral judgments. This was more than a revolt against the obtrusive personal author of the Thackeray type; it was also, in a sense, aimed at the impersonal narrator, the pure story-teller. Flaubert wanted to hide the very function of story-telling, as it were, to allow the story to tell and interpret itself, as far as this was possible; hence the narrator should, as he puts it, "transport himself into his characters." This free indirect speech is not an occasional device, nor something employed for a specific situation or person; it is a major instrument for achieving the Flaubertian type of novel. Flaubert's realism did not imply the sort of objectivity that belongs to natural science, an objectivity founded on communicable skill and authoritative control over the (imaginary) object; on the contrary, it meant an imaginative self-submergence in the object, participation in the imagined character's experience, in communication of the intuitive experience. ${ }^{21}$

In this stress upon self-effacing objectivity and figural empathy as criteria of Flaubert's style, Pascal seems to fall back on the "Germanic" tradition he criticizes and to join with Cohn's emphases (even quoting from the same letter of Flau-

21. Ibid., 98 . 


\section{Madame Bovary on Trial}

bert). The role of the narrator is subordinated, and identification with characters is stressed. Indeed Pascal's discussion of Flaubert is of ten close to that of Percy Lubbock in The Craft of Fiction. The "essence of the free indirect form" becomes for Pascal "the reproduction of the inner processes of the character." ${ }^{22}$ And criticisms are addressed to Flaubert when he departs from a norm of figural or character-oriented narration that Pascal himself places in theoretical question.

Pascal locates two major difficulties in Flaubert. "The first difficulty arises from the interweaving of [free indirect speech] and narratorial description. Once [free indirect speech] has become of frequent incidence in a novel, once we have become used to descriptions that are projections from the viewpoint of a character, we tend to expect it everywhere, and may find it confusing if the objective, narratorial mode is used instead. This is especially likely when few and unobtrusive indicators accompany [free indirect speech] passages." ${ }^{23}$ Thus, in discussing the visit of Emma and Léon to the wet-nurse, Pascal is disturbed by the detailed description of many items in the room which reflects "authorial interest" and "Flaubert's inclination towards realism in the more usual sense, a Balzacian concern for the social genre scene." This change of focus presumably "thwarts his most characteristic artistic purpose, the construction of the mental world of his characters." ${ }^{24}$

The second putative difficulty stems from "uncertainties" that "occasionally involve a further problem . . . inherent in the use of free indirect speech. It is a question of the language, the style, in which such passages are given. We have already seen what opportunities [free indirect speech] offers for reproducing the gestures and intonation of a character, the vivacity of his peculiar personal expression, perhaps his slang, in contrast to narratorial description and simple indirect speech. . . . Flaubert ... does not allow his characters a highly personalized idiom, but usually, when giving in indirect style the words or articulate thoughts of his characters, provides enough of a characteristic tang to enable us easily to identify their source. ...

22. Ibid., 107-8.

23. Ibid., 103 .

24. Ibid., 104 . 
But the personalization and differentiation is much less easily achieved when an author gives, through free indirect speech, the less formed, less articulated mental processes of a character, at a stage when they have not taken a recognizable shape." ${ }^{25}$

In certain passages, Pascal even finds what he terms "narratorial usurpation" where the use of language clearly goes beyond the capacities of a character and may ironically inflate desires and dreams to an uncomfortably excessive extent. For Pascal, usurpation transgresses the permissible limits of ironicempathetic narratorial inflexion to steal the scene from the character's own consciousness. It "seems to arise from Flaubert's obsession with style in the abstract, with 'le mot juste' and with structure and rhythm of sentence and paragraph, in the sense that, on occasions, when he is seeking to convey through [free indirect speech] the character's own perspective, his feeling of 'rightness' is determined not so much by the specific situation of the character as by the contemplating narrator, or perhaps here we should say by the author. For Hugo Friedrich understands the unremitting search for 'le mot juste,' this obsessive artistry, as Flaubert's means to counterbalance the world for which he felt such bitter distaste, to 'exorcise' the hateful, inane world he evokes in his novels." For Pascal, this "usurpation" in passages which "purport to reproduce the attitude and vision of characters" constitutes "not only confusion but a threat to a very delicate nerve of the work, since it may impute to a character-Emma Bovary, for instance-an aesthetic compensation she is far from seeking or feeling." ${ }^{26}$

Both these supposed difficulties are not anomalies but rather constitutive elements of Flaubert's narrative practice of which the free indirect style is emblematic. The shift from the perception or idiom of a character to that of the narrator or even the author is typical of Flaubert's approach to narration. The modulation of (empathetic) proximity and (ironic) distance within free indirect speech passages is writ large in the tropisms that take one from free indirect speech to objective narration, quoted monologue, or interior monologue. And at times the

25. Ibid.

26. Ibid., 110-11. 


\section{Madame Bovary on Trial}

tense relation between narrator or author and character may convert more or less internalized dialogue into a struggle for the possession of language or the right to describe a character, object, or impression. These at times wrenching shifts are indeed unsettling - as they proved to be both for the prosecutor at the trial and for literary critics ever since. But the reason is not purely formal or "stylistic" in any narrow sense. The question may be a question of style, but it is stylistic in a very broad sense that engages deeply disturbing social, political, and cultural issues. To see the question in terms of presumably formal difficulties that one imputes to Flaubert's narrative practice is both inaccurate in accounting for that practice and perhaps diversionary with respect to the larger issues.

Pascal quotes an especially perplexing passage from the famous Comices agricoles scene:

Her profile was so calm that it could not be deciphered. It stood out clear in the light of the oval of her bonnet which was tied with pale ribbons like blades of reeds. Her eyes gazed straight ahead through her curving lashes and, although wide open, seemed a little hampered by the cheek-bones, because of the blood that gently pulsated beneath her delicate skin. ... Her head inclined towards one shoulder, and you could see between her lips the pearly tips of her white teeth.

Is she playing a game with me? Rodolphe wondered. ${ }^{27}$

Pascal comments: "The wondering question of Rodolphe, so unemphatically linked to the description, makes it clear (if there was any uncertainty) that we have been absorbing his impression of Emma." ${ }^{28}$

Yet there emphatically is uncertainty about whose impressions and language we have been absorbing-and this uncertainty increases the shock effect of Rodolphe's concluding question. Certain of the perceptions in this passage are too delicate and refined for a man of Rodolphe's taste and sensibility, and the phrase introduced by "because" could be attributed to him only by an implausible stretch of the imagination. Indeed the

27. Quoted, ibid., 102.

28. Ibid., 103 . 


\section{Narrative Practice and Free Indirect Style}

entire sentence concerning Emma's protean eyes would not seem to make definite sense from any one or any combination of perspectives. It is unclear why wide-open eyes would seem "hampered" by cheek-bones because of blood pulsating beneath delicate skin. The word Pascal translates as "hampered" is "bridé." De Man (97) translates it as "slanted," thus giving an exotic twist to the passage. One might suggest the superiority of the more literal translation-"bridled." The image of a horse being pulled up by the bridle adds to the evocativeness and allusive range of the sentence. It anticipates the horse ride when Emma and Rodolphe will "make love" for the first time and after which Rodolphe will repair the bridle of a horse with a knife (a knife that intimates his proximity to both Charles and Léon who also carry knives-and the fact that Charles does is a sign of his resemblance to a "peasant" for Emma). One might say that Emma's eyes although wide open seem "bridled" by the cheekbones because the bridling action causes the blood to flow and to appear to frame or compress the eyes. But this would be a highly debatable interpretation, as would even more farfetched ones it might call out. In any case, the suggestive discursive indefiniteness of this grammatically precise sentence is typical of Flaubert as writer and narrator rather than of Rodolphe as character.

The relation of Flaubert's narrative practice to his projects is at least dual. On the one hand, the role of "objective" narration and of shifting perspectives that seem to return to impassivity in their own way might be related to the ideal of pure art. The modulations of perspective or voice, which may at times be abrupt or extreme, create such a multiplicity of points of view that they seem to cancel out or erase one another. Multiplication of positions of the narrating subject and of relations to the narrated object would seem through profusion or excess to engender the effect of white noise and to return the text to silence. This effect is in one sense that of language writing or speaking itself but not emanating from a secure or fixed source and not communicating a precise message or evaluative position with respect to characters and events. The limit of this mutual cancellation of narrative perspectives would come in the pure exchange of clichés or of entirely conventionalized 
modes of discourse for which no one-author, writer, narrator, or character-would bear responsibility. Pure art would be the book about nothing in the sense of a book of pure cliché presented in a mutually self-cancelling or bewilderingly indeterminate multiplicity of perspectives. The effect would be like that of a self-destructive, negative dialectic of banalized proverbs that contradict one another to provide no guidance whatsoever. The position of the narrator would be one of stable ironic transcendence placing him in a secular position analogous to that of a hidden God-but one with little to distinguish him from his satanic adversary. (Here the Comices agricoles scene might be taken as paradigmatic.)

Yet this limit of pure art, while it may be approximated, is never reached. It is countered by more carnivalesque tendencies. But the role of the carnivalesque is itself multiple in Flaubert. I shall simply mention in summary fashion three positions of the carnivalesque in Madame Bovary and return to them in later chapters.

First, the carnivalesque is represented in the narrated world of the novel as distorted, avoided, repressed, or suppressedand this very status exacerbates the ugliness and deadly repetitiveness of everyday routine. There are, as we shall see, numerous instances of the distortion or repression of the carnivalesque in the world represented in the novel and, if anything, one should be surprised by their very ubiquitousness. But, second, the ideal of pure art is itself carnivalized in Madame Bovary, specifically through the variable empathetic-ironic handling of its analogues-Emma's romantic quest for absolute love, Charles' idolatry of Emma, Binet's perfectionist grinding of gratuitous objects, Homais' striving for a positivistic language of full mastery over the "other." Third, the very multiplication of narrative positions and of relations to objects of narration itself retains a resonance and an insistence that counteracts effects of mutual cancellation. It rehabilitates the carnivalesque on the level of narrative practice or "style" itself. Thus, while the carnivalesque is repressed in the narrated world of the novel (for example, in the lives of characters), it is to some extent reactivated in the mode of narration. The various perspectives and voices in the novel remain active to provide a 
myriad of more or less subtle perspectives and evaluations vis-à-vis characters and events. The effect here is a carnivalization of narrative voice and a dissemination of the narrator-at times the author-in the text. Often this creates the possibility of delicate judgments and value-shadings that are both tied to situations and indicative of flexible normative principles. At other times, the result is a hyperbolic proliferation of points of view and dialogical relations that seem to wreak havoc with any semblance of stable judgment. This narrative practice can be seen as a self-questioning mode of satire that arises in the context of perceived cultural crisis: the problem confronted by the reader is that of the degrees and ways in which it is both poison and antidote in relation to the larger sociocultural complex it confronts. Flaubert's world is in this sense an uneasy and discomforting world that requires a line-by-line reading of novels and of life, and it is still in many fundamental ways the world in which we continue to live for good and ill. 